\title{
Dynamika vyplavování pesticidních látek v povodí Čechtického potoka
}

\section{JAKUB DOBIÁŠ, MILAN KOŽELUH, ANTONÍN ZAJÍČEK, PETR FUČíK, MAREK LIŠKA}

Klíčová slova: pesticidní látky - automatické vzorkování - srážko-odtoková událost - látková bilance - VN Švihov

\section{SOUHRN}

Využití automatických vzorkovačů se stává běžnou součástí detailního - bilančního monitoringu koncentrací a odnosů látek. Prưměrné výsledky běžného monitoringu bodových vzorkư jsou oproti reálnému stavu často podhodnocené $[1,2]$.

Povodí Čechtického potoka odvodňuje jedno z nejvíce zemědělsky obhospodařovaných území v celém povodí vodárenské nádrže Švihov na Želivce. Od roku 2012 zde státní podnik Povodí Vltavy provozuje vzorkovací stanici. Pesticidní látky a jejich metabolity jsou analyzovány bud' ve slévaných 14denních vzorcích, nebo jsou na základě průtoku (v prípadě srážko-odtokových událostí) odebrány i dvoudenní slévané a bodové vzorky.

Postupným zdokonalováním vzorkovacího systému bylo nejvíce hydrologických událostí zachyceno v roce 2015 a 2016. Z hlediska hydrologických podmínek a výskytu pesticidních látek byl rok 2016 oproti předchozímu roku zajímavější, publikovaná data tedy pochází převážně z roku 2016. Výsledky z kontinuálního měření ukázaly nárůsty koncentrací a odnosů mateřských pesticidních látek na jaře a jejich metabolitů v průběhu léta. Celková látková bilance námi sledovaných pesticidů a jejich metabolitů byla 3,88 kg (4-11/2016, $Q_{\text {prům }}=63,5$ l. $\left.\mathrm{s}^{-1}\right)$. Z dlouhodobého hlediska se mění i skladba používaných pesticidů, patrné je to na príkladu terbuthylazinu (pěstování kukuřice). V povodí se nyní více vyskytují jeho metabolity a byl pravděpodobně nahrazen jinými účinnými látkami (isoxaflutole, cyprosulfamide a thiencarbazon-methyl). Při snaze detekovat nové účinné látky mají laboratoře oproti zemědělským aplikacím výrazné zpoždění. Proto je třeba neustálý vývoj analýz a sledování nových trendů.

Nejzajímavější výsledky však poskytují zachycené hydrologické události, kdy se koncentrace oproti kontinuálnímu sledování zvýší (nebo naopak sníží) rádově, a to během desítek minut. Dynamika vyplavování živin a speciálních organických látek během srážko-odtokových událostí se ukazuje být natolik významná, že bez detailního vzorkovacího schématu mưžeme koncentrace a následné odnosy látek pouze odhadovat.

\section{ÚVOD}

Časté extrémní změny v koncentracích pesticidních látek a jejich metabolitů ve vzorcích povrchových vod v rámci provozního monitoringu vedou k otázce, jaké množství je těchto cizorodých látek ve vodním prostředí doopravdy prítomno [3, 4]. Intenzivněji se tím začaly zabývat i vodohospodářské laboratoře státního podniku Povodí Vltavy. Pro účely přesnějšího odhadu odnosủ živin a speciálních organických látek byla v roce 2012 zprovozněna automatická vzorkovací stanice na Čechtickém potoce. Ten odvodňuje zemědělsky intenzivně obdělávané povodí a po soutoku se Sedlickým potokem a prưchodu zdrží
VN Němčice ústí do VN Švihov pobliž její hráze. Od roku 2015 analyzujeme vedle směsných kontinuálně odebíraných vzorků i bodové vzorky v průběhu hydrologických událostí a náhlého zvýšení průtoků. Ukázalo se, že dynamiku pesticidních látek běžným vzorkováním nelze spolehlivě podchytit [1], i když se $v$ tocích za našimi zády běžně odehrává.

Zachycení hydrologických událostí ve vzorcích je velice důležité pro kvantitativní, ale i kvalitativní analýzu [1, 2]. Některé látky se mohou ve vodě vyskytnout pouze při srážko-odtokové události [5], a to ještě za podmínky, že jejich aplikace proběhla těsně před tím. Znalost přeměny rodičovských látek na další rozpadové produkty je pro vyhodnocení vlivu použivání pesticidů zásadní. Důležitá je také znalost povodí, zdrojů znečištění [5] a přehled o aplikacích látek na pěstované plodiny v povodí [4]. Výše zmíněné podmínky jsou důvodem častého podhodnocení bilancí živin i speciálních organických látek, které nevychází z kontinuálního měření $[1,2,6]$.

\section{METODIKA}

Automatická vzorkovací stanice se skládá ze vzorkovače ISCO Avalanche (pro 14 diskrétních vzorků), který je autonomně napájen elektrickou energií ze dvou solárních panelů umístěných na střeše stanice. Součástí stanice je srážkoměr, sondy pro měření zákalu, vodivosti a modul pro kontinuální měření výšky hladiny (tzv. Bubbler). Pro daný profil byla změřena průtoková křivka, podle které je automaticky (podle výšky hladiny) odvozován okamžitý průtok. Veškeré signály jsou ze vzorkovače svedeny do přenosové GSM stanice Fiedler.

Odběrové schéma vzorkovače je nastaveno na dva provozní režimy, které se spouští podle dané situace. Kontinuální vzorkování probíhá nepřetržitě v periodě po čtyřech hodinách. Vznikne tak jeden integrální slévaný vzorek, který reprezentuje celou 14denní periodu. $V$ prípadě potřeby je možné analyzovat

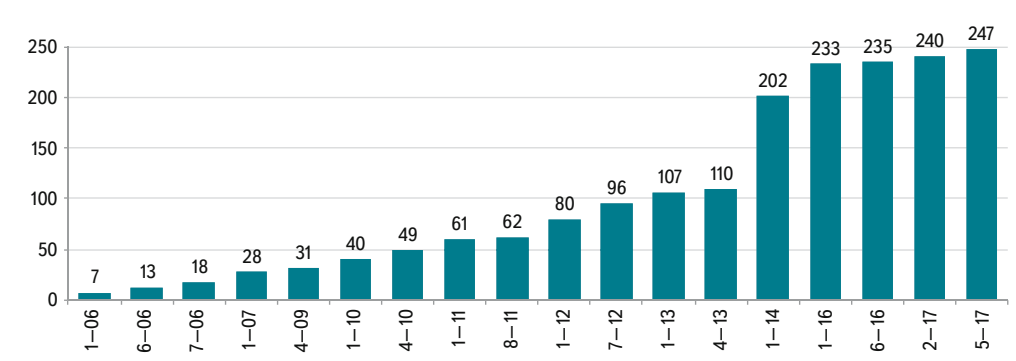

Obr. 1. Vývoj počtu analyzovaných pesticidů a jejich metabolitů ve VHL Povodí VItavy v letech 2006-2017

Fig. 1. The number of analyzed pesticides and their metabolites in the laboratory of VItava River Basin (2006-2017) 


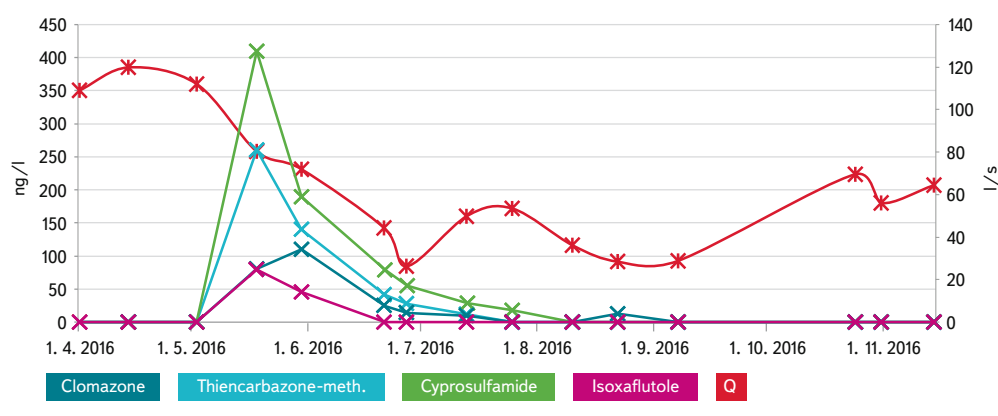

Obr. 2. Koncentrace herbicidních látek v povrchové vodě, kontinuální vzorkování Fig. 2. Concentrations of herbicides in surface water, continuous sampling

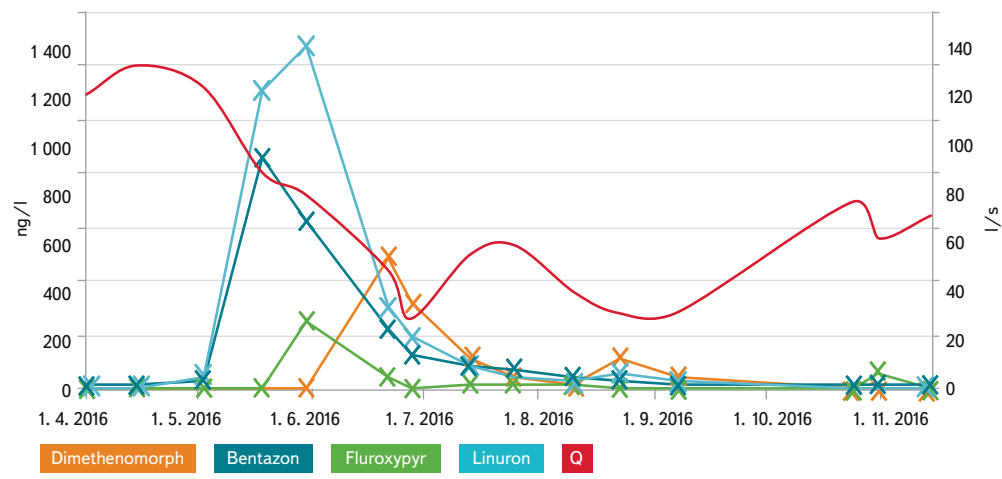

Obr. 3. Vysoké koncentrace fungicidní látky (dimethenomorph) a tří herbicidních látek (bentazon, fluoxypyr a linuron) v jarním období

Fig. 3. High concentrations of fungicide (dimethenomorph) and three herbicides (bentazon, fluoxypyr a linuron) in spring

i dvoudenní slévaný vzorek. Pro vzorkování hydrologické události je vyhrazena polovina vzorkovnic (7 ks). Při zvýšení hladiny se automaticky spustí vzorkování prostých vzorků, a to v intervalu sedmi hodin. Toto schéma bylo na Čechtickém potoce uplatněno v následujících obdobích: 10. 3.-30. 11. 2015 a 1. 4.-28. 11. 2016. $\checkmark$ zimním období není stanice provozována, protože nelze zajistit její bezproblémový provoz v období mrazů.

Pesticidy a metabolity jsou v laboratoři ze vzorků následně stanoveny př́mým nástřikem vzorku vody do kapalinového chromatografu (LC). Detekce je provedena pomocí hmotnostního detektoru na principu trojitého kvadrupólu (MS/MS) v režimu pozitivní nebo negativní ionizace. Analýza vzorků probíhá po skupinách (tzv. módech), které se liší způsobem předúpravy vzorku, různými chromatografickými podmínkami a režimem ionizace. Analyzovány byly tři skupiny pesticidních látek a jejich metabolické produkty: triazinové herbicidy (např. terbuthylazin), chloracetanilidy (např. alachlor, metazachlor, metolachlor) a pesticidy patřící do skupiny derivátů kyseliny močové - tzv. urony (např. linuron, chlortoluron).

Pesticidy a jejich metabolity jsou v posledních letech hlavními prioritami sledování kvality vod $[3,6,7]$. To je patrné i na vývoji množství měřených pesticidů a jejich metabolitů (obr. 1) v laboratořích Povodí Vltavy. Nové analyty se zavádí s ohledem na legislativu (WFD), požadavky Mezinárodní komise pro ochranu Labe a především databázi pesticidů ČHMú [8], založenou na základě spotřeby pesticidů $v$ ČR. Důležitými podněty jsou nové trendy v zemědělství a publikované výsledky.

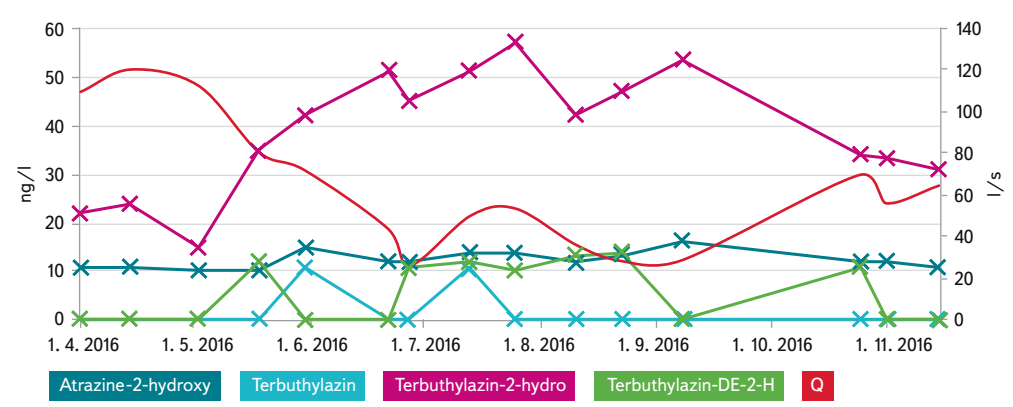

Obr. 4. Koncentrace terbuthylazinu a jeho metabolitů; průměrný průtok během odběru směsných vzorků

Fig. 4. Concentrations of terbuthylazine and his metabolites; average flow during the sampling

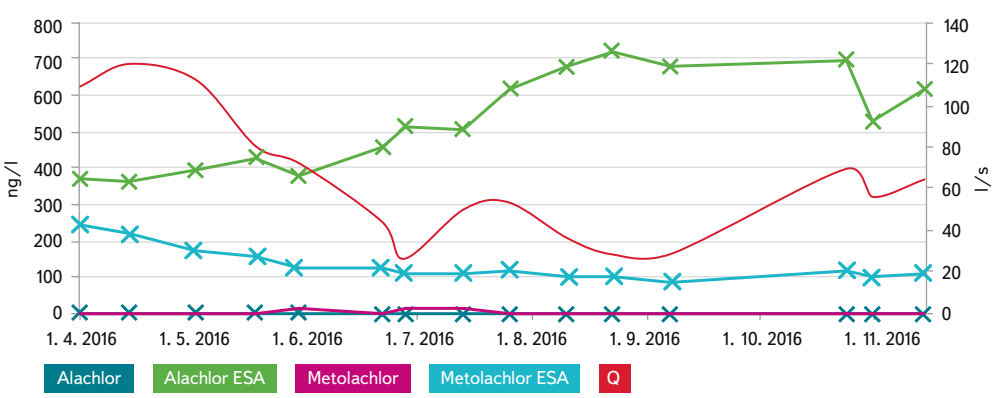

Obr. 5. Sezonní průběh koncentrace alachloru, metolachloru a jejich metabolitů Fig. 5. Seasonal course of alachlor, metolachlor and their metabolites

\section{VÝSLEDKY A DISKUSE}

Rok 2016 byl srážkově průměrný až podprưměrný $\left(Q_{\text {prưm }}(4-11 / 2016)=63,5\right.$ l·s $\left.{ }^{-1}\right)$. I přes tuto skutečnost přinesl ve srovnání s extrémně suchým rokem 2015 $\left(Q_{\text {prům }}(6-12 / 2015)=54,7 \mid \cdot S^{-1}\right)$ relevantnější výsledky o vyplavování pesticidních látek (tabulka 1).

Nejvyšší koncentrace ve slévaných vzorcích byly naměřeny u metazachoru ESA (2 $\left.840 \mathrm{ng} \cdot \cdot^{-1}\right)$, linuronu (1 $\left.270 \mathrm{ng} \cdot \cdot^{-1}\right)$ a bentazonu (860 ng. $\left.\cdot^{-1}\right)$. Maximální koncentrace byly během hydrologických událostí naměřeny u linuronu (9540 ng. $\left.{ }^{-1}\right)$, bentazonu (4 $\left.500 \mathrm{ng} \cdot \mathrm{l}^{-1}\right)$, cyprosulfamidu (5 $900 \mathrm{ng} \cdot \mathrm{l}^{-1}$ ), isoxaflutolu (3 $500 \mathrm{ng} \cdot \mathrm{l}^{-1}$ ), thiencarbazone-methylu (2 $\left.800 \mathrm{ng} \cdot \mathrm{l}^{-1}\right)$ a dalších látek. Podobně jako u předchozích výsledků i zde se v nejvyšších koncentracích vyskytují všechny tři složky již zmíněného komerčního př́pravku Adengo.

Některé látky se $v$ povodí vyskytovaly pouze během srážko-odtokových událostí (ve slévaných vzorcích se nevyskytovaly vưbec, nebo byly pod mezí stanovitelnosti). Jedná se např. o fungicidy azoxystrobin a propiconazol, insekticidy clothianidin a thiacloprid, chloracetanilidové pesticidy metazachlor a metolachlor a další. Koncentrace těchto látek během epizod jsou měřitelné, přesto velmi nízké (tabulka 1).

\section{Výsledky kontinuálního vzorkování pesticidních látek}

Na výsledcích ze směsných vzorků jsou dobře patrné změny $v$ koncentraci způsobené vyšším průtokem a jarní (prípadně podzimní) aplikací pesticidů na zemědělskou půdu (obr. 2, 3). Vysoké koncentrace vybraných herbicidů a fungicidů byly měřeny ve vzorcích koncem jara a začátkem léta, zatímco po zbytek vzorkovacího období nebyly detekovány vůbec, nebo v rádově nižších koncentracích. Jarní maxima nalezených látek se mohou částečně překrývat nebo naopak - jako v prípadě bentazonu (kukuřice, brambory, obilí) 


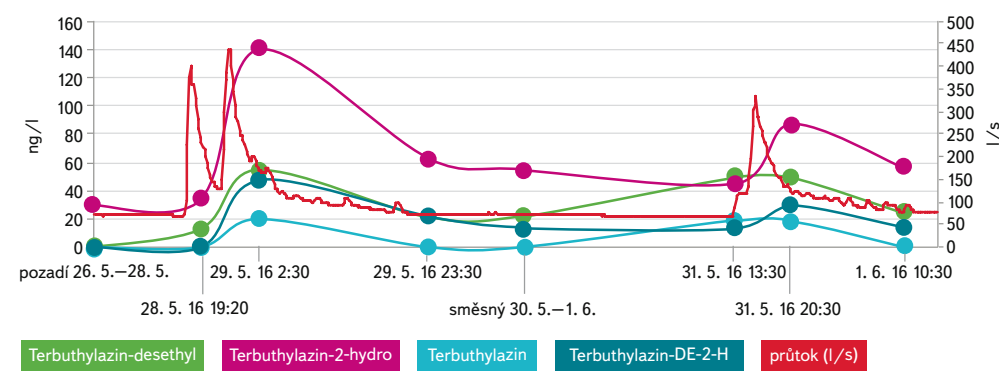

Obr. 6. Vývoj koncentrací terbuthylazinu a jeho metabolitů během srážkové epizodní události (28. 5.-1. 6. 2016); bodové a směsné dvoudenní vzorky

Fig. 6. Concentrations of terbuthylazine and his metabolites during the hydrological event (28 $8^{\text {th }}$ May- $1^{\text {st }}$ June 2016); simple and continuous sampling

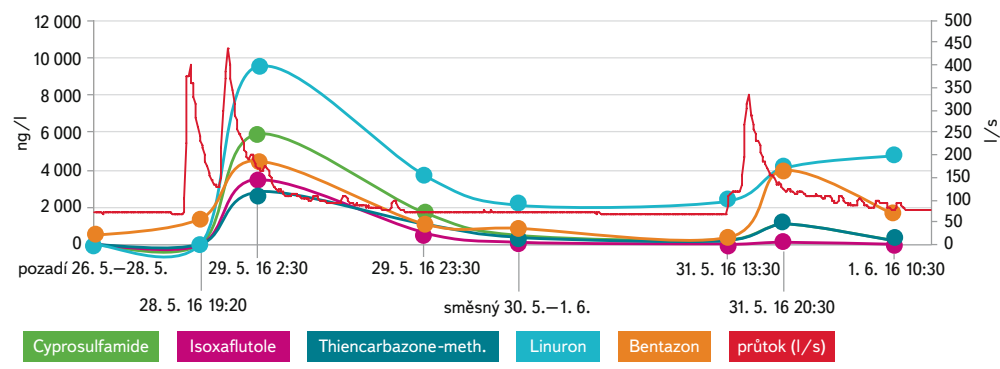

Obr. 7. Vývoj koncentrací vybraných pesticidů a metabolitů během srážkové epizodní události (28. 5.-1. 6. 2016); bodové a směsné dvoudenní vzorky

Fig. 7. Concentrations of selected pesticides and their metabolites during the hydrological event (28 $8^{\text {th }}$ May-1 $1^{\text {st }}$ June 2016 ); simple and continuous sampling

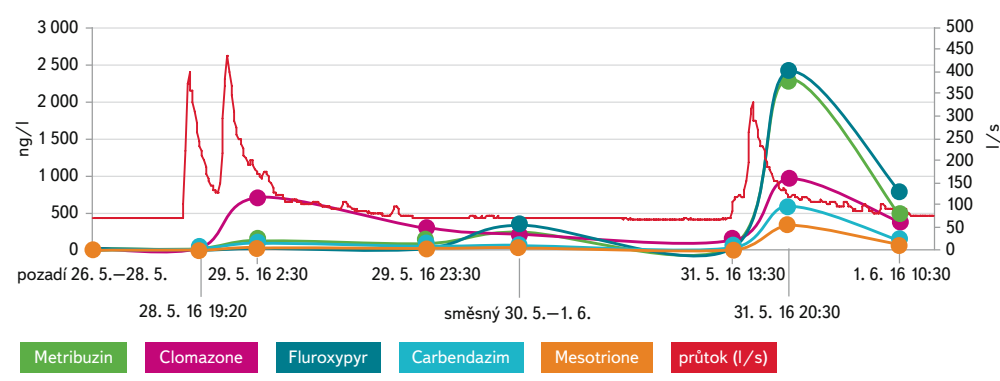

Obr. 8. Vývoj koncentrací vybraných pesticidů a metabolitů během srážkové epizodní události (28. 5.-1. 6. 2016); bodové a směsné dvoudenní vzorky

Fig. 8. Concentrations of selected pesticides and their metabolites during the hydrological event (28 ${ }^{\text {th }}$ May-15t June 2016); simple and continuous sampling

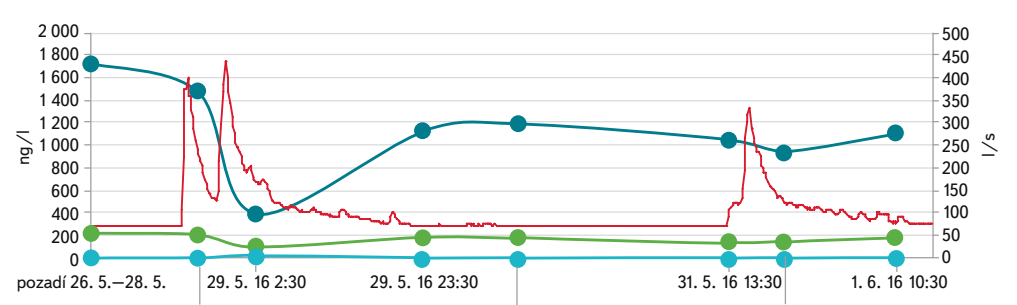

$$
\text { 28. } 5.1619: 20
$$

směsný 30. 5.-1. 6 .

31. $5.1620: 30$

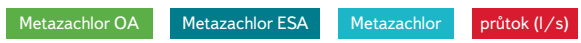

Obr. 9. Vývoj koncentrací metazachloru a jeho metabolitů během srážkové epizodní události (28. 5.-1. 6. 2016); bodové a směsné dvoudenní vzorky Fig. 9. Concentrations of metazachlor and his metabolites during the hydrological event (28 ${ }^{\text {th }}$ May-1 ${ }^{\text {st }}$ June 2016); simple and continuous sampling a dimethenomorphu (mj. plísňová onemocnění brambor), viz obr. 3. Látky byly pravděpodobně aplikovány $v$ jiném období, např. sušší a teplejší část roku u účinné látky dimethenomorph. Dalším příkladem vysokých koncentrací pesticidů v jarním období je linuron (v zájmovém povodí pravděpodobně aplikovaný na brambory, kukuřici a obiloviny). V Čechtickém potoce je koncentrační maximum patrné v květnu a červnu (obr. 3). Linuron účinkuje na povrch rostlin i kořenové systémy, aktivně tedy působí i v půdním profilu, odkud je vyplavován do povrchových vod.

Zachycené vysoké koncentrace účinných látek (obr. 2-4) korespondujís pěstovanými plodinami v povodí. Kukuřice je po pšenici druhou nejpěstovanější plodinou (v roce 2015 19,3 \% z celkové plochy povodí Čechtického potoka, v roce 2016 pak 19,1\%). Pěstování pšenice pokrývalo 29,4\% v roce 2015, resp. 23,3 \% (2016). Další hojně pěstované plodiny v povodí byly řepka 11,4 \% (2015) a 9,9\% (2016) a brambory (5,2\% v roce 2015 a 9,8 \% v roce 2016) $[5,9]$.

$\checkmark$ rámci sledování byly detekovány látky či metabolity látek, jejichž koncentrace jsou $v$ průběhu roku vysoké a prakticky konstantní (obr. 4, 5). To mohlo být způsobeno častějšími aplikacemi účinné látky na zemědělskou půdu v průběhu roku nebo vysokou persistencí metabolitů v půdě a vodě. Př́kladem jsou metabolity herbicidu chloridazonu. Stabilita mateřské látky je podle publikovaných informací velice proměnlivá a nebyla detekována nad mezí stanovitelnosti (10 $\left.\mathrm{ng}^{-{ }^{-1}}\right)$ ani jednou. Oproti tomu metabolity chloridazon desphenyl a chloridazon methyl-desphenyl jsou poměrně stabilní a ve směsných vzorcích byly $v$ průběhu vzorkovacího období naměřeny pozitivní koncentrace metabolitů chloridazonu v rozmezí (57-110 ng. $\cdot^{-1}$, resp. 12-22 ng..$^{-1}$ ) ve všech vzorcích (tabulka 1). V průběhu hydrologických událostí pak docházelo k jejich naředění. Podobný výskyt byl zaznamenán i u chloracetanilidových pesticidů metolachloru a metazachloru a jejich metabolitů (obr. 5).

Stabilní výskyt metabolitů je patrný i u dalších látek. V povodí Sedlického a Čechtického potoka se v souvislosti s pěstováním kukuřice velice často používala pesticidní látka terbuthylazin (obr. 4). Ta nahradila v roce 2005 zakázaný atrazin a byla v povodí stabilně měřena ve vysokých koncentracích [4]. V posledních několika letech došlo na některých profilech v povodí k rádovému snížení koncentrací a můžeme tak předpokládat, že byla v prípravcích postupně nahrazena za novější a účinnější látky. Jedná se například o pesticidní prípravek, který se prodává pod komerčním názvem Adengo a obsahuje tři účinné látky (isoxaflutole, cyprosulfamide a thiencarbazone-methyl) (obr. 2).

Zajímavý vývoj koncentrací alachloru a jeho metabolitu alachloru ESA byl pozorován v celém vzorkovacím období (obr. 5). Zatímco užívání alachloru bylo zakázáno v roce 2008 a jeho koncentrace jsou pod mezí stanovitelnosti, koncentrace jeho stabilnějšího metabolitu (formy ESA) jsou stále vysoké. Zpravidla je pozorován dlouhodobý pokles této látky [4], na profilu Leský Mlýn v roce 2016 tomu tak ovšem nebylo a koncentrace $\vee$ průběhu roku spíše rostla. Prrićinou mohla být hydrologická situace a dlouhodobá perzistence metabolitu v pưdách nebo nepovolená recentní aplikace.

\section{DYNAMIKA VYPLAVOVÁNÍ PESTICIDNÍCH LÁTEK BĚHEM HYDROLOGICKÝCH UDÁLOSTÍ}

Zatímco koncentrace pesticidů během kontinuálního sledování nabývají hodnot desítek až stovek ng.l-1, v průběhu srážkových událostí se koncentrace často zvýší rádově až na tisíce ng.1-1 (tabulka 1). Ze čtyř zachycených událostí v roce 2016 uvádíme převážně výsledky z jarní epizody (složené ze dvou menších), viz obr. 6-10. Převážná většina pesticidů vč. jejich metabolitů reagovala na rychlé zvýšení průtoku zvýšením koncentrací (obr. 6-8). Srážky, které způsobily zvýšení průtoku v potoce (cca $8 \times$ ), byly poměrně vydatné s rychlým nástupem. Dá se tedy predpokládat, že většina srážkové vody byla do potoka odvedena po povrchu, resp. promývala vrchní vrstvy půdy. Zvýšení koncentrací látek tak nastalo se zpožděním o cca devět hodin. Jinak by tomu bylo při mírných 
Tabulka 1. Přehled všech detekovaných pesticidů a jejich metabolitů v závěrovém profilu Čechtického potoka (profil Leský Mlýn) v období od 1. 4. do 30. 11. 2016; D - deriváty (metabolity), $H$ - herbicidy, F-fungicidy, I - insekticidy, R- regulátory růstu, $n$ - nedetekováno

Table 1. Overview of all detected pesticides and their metabolites on the closing profile of the Čechtický brook (\$t April-30 th November 2016); D - derivatives (metabolites), $H$ - herbicides, F-fungicides, I - insecticides, $R$ - growth regulator, $n$ - undetected

\begin{tabular}{|c|c|c|c|c|c|}
\hline \multicolumn{2}{|l|}{ Čechtický potok } & \multicolumn{2}{|c|}{ Pravidelné odběry } & \multicolumn{2}{|l|}{ Epizody } \\
\hline látka & typ & $\begin{array}{l}\text { počet detekcí } \\
\text { (počet vzorků) }\end{array}$ & $\begin{array}{l}\text { rozsah koncentrace } \\
\left(\left.\mathrm{ng} \cdot\right|^{-1}\right)\end{array}$ & $\begin{array}{l}\text { počet detekcí } \\
\text { (počet vzorků) }\end{array}$ & $\begin{array}{l}\text { rozsah koncentrace } \\
\left(\left.\mathrm{ng} \cdot\right|^{-1}\right)\end{array}$ \\
\hline $2,4-D$ & & $0(15)$ & $n$ & $2(18)$ & $12-25$ \\
\hline Acetochlor ESA & $\mathrm{D}$ & $15(15)$ & $58-94$ & $18(18)$ & $39-89$ \\
\hline Acetochlor OA & $D$ & $4(15)$ & $21-30$ & $4(18)$ & $23-33$ \\
\hline Alachlor ESA & D & $15(15)$ & $360-717$ & $18(18)$ & $146-717$ \\
\hline Atrazin-desethyl & $\mathrm{D}$ & $2(15)$ & $11-11$ & $2(18)$ & $11-12$ \\
\hline Atrazine-2-hydroxy & $D$ & $13(15)$ & $10-16$ & $17(18)$ & $10-27$ \\
\hline Azoxystrobin & $\mathrm{F}$ & $0(15)$ & $n$ & $2(18)$ & 19-150 \\
\hline Bentazon & $\mathrm{H}$ & $15(15)$ & $15-860$ & $17(18)$ & $10-4500$ \\
\hline Benzotriazol & & $15(15)$ & $56-260$ & $18(18)$ & $46-211$ \\
\hline Benzotriazol methyl & D & $15(15)$ & $55-134$ & $18(18)$ & $57-121$ \\
\hline Carbendazim & $\mathrm{F}$ & $2(15)$ & $22-27$ & $8(18)$ & $10-590$ \\
\hline Clomazone & $\mathrm{F}$ & $5(15)$ & $10-110$ & $10(18)$ & $10-950$ \\
\hline Clothianidin & । & $0(15)$ & $n$ & $2(18)$ & $27-29$ \\
\hline Cyprosulfamide & $\mathrm{H}$ & $6(15)$ & $18-410$ & $10(18)$ & $13-5900$ \\
\hline DEET & । & $15(15)$ & $13-290$ & $18(18)$ & $12-334$ \\
\hline Difenoconazole & $\mathrm{F}$ & $2(15)$ & $12-36$ & $0(18)$ & $\mathrm{n}$ \\
\hline Dimetachlor & $\mathrm{H}$ & $0(15)$ & $n$ & $1(18)$ & $14-14$ \\
\hline Dimethachlor ESA & $D$ & $3(15)$ & $21-26$ & $1(18)$ & $21-21$ \\
\hline Dimethenomorph & $\mathrm{F}$ & $7(15)$ & $23-490$ & $5(18)$ & $12-110$ \\
\hline Diuron & & $0(15)$ & $n$ & $1(18)$ & $11-11$ \\
\hline Epoxiconazol & $\mathrm{F}$ & $0(15)$ & $n$ & $3(18)$ & $12-45$ \\
\hline Fluopicolide & $\mathrm{F}$ & $2(15)$ & $11-17$ & $0(18)$ & $n$ \\
\hline Fluroxypyr & $\mathrm{H}$ & $6(15)$ & $10-250$ & $10(18)$ & $13-2400$ \\
\hline Chloridazon desphen. & $\mathrm{D}$ & $15(15)$ & $57-110$ & $16(18)$ & $54-110$ \\
\hline Chloridazon met.des. & $\mathrm{D}$ & $15(15)$ & $12-22$ & $17(18)$ & $11-21$ \\
\hline Chlorotoluron & $\mathrm{H}$ & $2(15)$ & $17-21$ & $5(18)$ & $13-43$ \\
\hline Chlorsulfuron & $\mathrm{H}$ & $1(15)$ & $13-13$ & $0(18)$ & $\mathrm{n}$ \\
\hline
\end{tabular}


Čechtický potok

\begin{tabular}{|c|c|c|c|c|c|}
\hline látka & typ & $\begin{array}{l}\text { počet detekcí } \\
\text { (počet vzorků) }\end{array}$ & $\begin{array}{l}\text { rozsah koncentrace } \\
\left(\mathrm{ng} \cdot \mathrm{l}^{-1}\right)\end{array}$ & $\begin{array}{l}\text { počet detekcí } \\
\text { (počet vzorků) }\end{array}$ & $\begin{array}{l}\text { rozsah koncentrace } \\
\left(\mathrm{ng} \cdot \mathrm{l}^{-1}\right)\end{array}$ \\
\hline Imidacloprid & $\mathrm{H}$ & $3(15)$ & $11-17$ & $7(18)$ & $11-78$ \\
\hline Isoproturon & $\mathrm{H}$ & $3(15)$ & $16-17$ & $4(18)$ & $12-25$ \\
\hline Isoxaflutole & $H$ & $2(15)$ & $46-80$ & $6(18)$ & $29-3500$ \\
\hline Linuron & $\mathrm{H}$ & $10(15)$ & $29-1270$ & $14(18)$ & $11-9540$ \\
\hline Mandipropamid & $\mathrm{F}$ & $2(15)$ & $18-120$ & $2(18)$ & $12-18$ \\
\hline MCPA & $\mathrm{H}$ & $3(15)$ & $13-27$ & $3(18)$ & $12-27$ \\
\hline Mesotrione & $\mathrm{H}$ & $2(15)$ & $17-46$ & $6(18)$ & $10-320$ \\
\hline Metalaxyl & $\mathrm{F}$ & $5(15)$ & $18-170$ & $3(18)$ & $16-49$ \\
\hline Metamitron & $\mathrm{H}$ & $1(15)$ & $20-20$ & $0(18)$ & $n$ \\
\hline Metazachlor & $H$ & $0(15)$ & $n$ & $3(18)$ & $12-23$ \\
\hline Metazachlor ESA & $\mathrm{D}$ & $15(15)$ & $625-2840$ & $18(18)$ & 383-1770 \\
\hline Metazachlor OA & $\mathrm{D}$ & $15(15)$ & $47-516$ & $18(18)$ & $37-326$ \\
\hline Metolachlor & $\mathrm{H}$ & $3(15)$ & $11-16$ & $4(18)$ & $17-72$ \\
\hline Metolachlor ESA & $\mathrm{D}$ & $15(15)$ & $83-240$ & $18(18)$ & $45-218$ \\
\hline Metolachlor OA & $\mathrm{D}$ & $3(15)$ & $22-27$ & $2(18)$ & $22-24$ \\
\hline Metribuzin & H & $4(15)$ & $14-120$ & 9 (18) & $11-2300$ \\
\hline Parathion-methyl & I & 0 (15) & $n$ & $1(18)$ & $22-22$ \\
\hline Pethoxamid & $\mathrm{H}$ & $0(15)$ & $n$ & $1(18)$ & $13-13$ \\
\hline Propiconazol & $\mathrm{F}$ & $0(15)$ & $n$ & $1(18)$ & $13-13$ \\
\hline Tebuconazol & $\mathrm{F}$ & $4(15)$ & $11-15$ & $10(18)$ & $12-54$ \\
\hline Terbuthylazin-DE-2-H & $\mathrm{D}$ & $6(15)$ & $10-14$ & $10(18)$ & $10-47$ \\
\hline Terbuthylazin & $\mathrm{H}$ & $2(15)$ & $11-11$ & $5(18)$ & $19-28$ \\
\hline Terbuthylazin-2-hydro & $\mathrm{D}$ & $15(15)$ & $15-57$ & $18(18)$ & $25-140$ \\
\hline Terbuthylazin-desethyl & $\mathrm{D}$ & $1(15)$ & $10-12$ & $9(18)$ & $13-55$ \\
\hline Thiacloprid & । & $0(15)$ & $n$ & $2(18)$ & $10-40$ \\
\hline Thiamethoxam & । & $1(15)$ & $13-13$ & $2(18)$ & $21-41$ \\
\hline Thiencarbazone-meth. & $\mathrm{H}$ & $5(15)$ & $12-260$ & $9(18)$ & $13-2800$ \\
\hline Trinexapac-ethyl & R & $0(15)$ & $n$ & $1(18)$ & $18-18$ \\
\hline
\end{tabular}




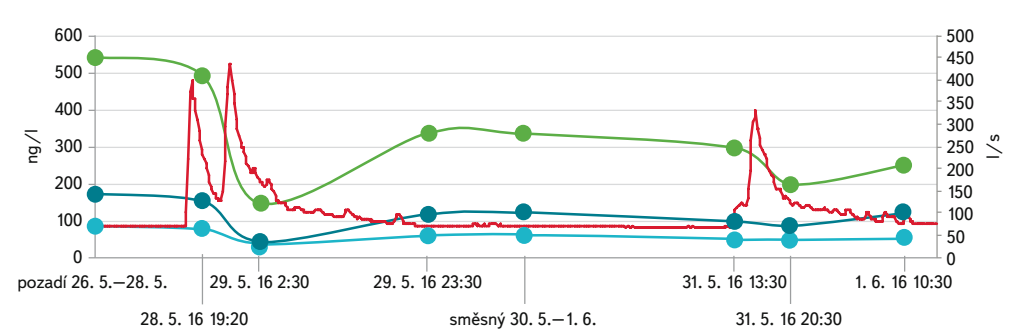

Alachlor ESA Metolachlor ESA Acetochlor ESA pruitok (I/s)

Obr. 10. Vývoj koncentrací metabolitů chloracetanilidových pesticidů během srážkové epizodní události (28. 5-1. 6. 2016); bodové a směsné dvoudenní vzorky

Fig. 10. Concentrations of chloracetanilid metabolites during the hydrological event (28 $8^{\text {th }}$ May-1 $1^{\text {st }}$ June 2016); simple and continuous sampling

a vytrvalých srážkách, kdy by podpovrchový odtok vytlačil podzemní a podpovrchové vody s cizorodými látkami „před sebou“ [5].

Koncentrační křivky terbuthylazinu a jeho metabolitů měly během epizody prakticky stejný průběh (obr. 6) a lišily se mezi sebou pouze v látkovém množství až o jeden rád. Podobný průběh koncentrací s přímou závislostí na průtoku měly i ostatní látky, které byly na jaře často detekovány i během kontinuálního vzorkování - např. linuron, bentazon a cyprosulfamide (obr. 7). Látky isoxaflutole, cyprosulfamide a thiencarbazone-methyl (prípravek Adengo) se při hydrologické epizodě vyskytovaly ve vysokých koncentracích (obr. 6), což svědčí o jejich používání na polích v povodí.

Zajímavou skutečností byla rozdílná dynamika vyplavování některých látek. Zatímco koncentrace některých pesticidů byly ve vodě tím vyšší, čím vyšší byl průtok, koncentrace jiných látek (např. fluroxypyr, metribuzin a mesotrione) se zvýšily až při druhé, výrazně menší srážko-odtokové události (obr. 8). Některé látky však mohly být v povodí aplikovány až po první srážce.

Zcela odlišný vývoj koncentrací během srážkové epizody byl naměřen u většiny metabolitů chloracetanilidových pesticidů (obr. 9, 10). V období zvýšeného průtoku v Čechtickém potoce došlo ke snižení koncentrací a k naředění všech detekovaných metabolitů metazachloru, alachloru, acetochloru a metolachloru. Tyto metabolity jsou velice persistentní a ve slévaných vzorcích byly na lokalitě detekovány po celý rok, proto jsou pravděpodobně za vyšších průtoků v povrchové vodě úměrně srážkám "nařed’ovány“.

\section{LÁTKOVÁ BILANCE}

Na základě zjištěných údajů byl proveden výpočet látkové bilance celkového odnosu pesticidních látek z povodí Čechtického potoka v průběhu vzorkovacího období (4-11/2016). Do látkové bilance nebyly započteny speciální organické látky (např. DEET, benzotriazol a některé další). Epizody byly $\vee$ bilanci zahrnuty pouze $v$ rámci slévaných vzorků. Celkový odnos pesticidů činil ve vzorkovacím období 3,88 kg (obr. 11). Vzhledem k hydrologické situaci a průměrnému průtoku $63,5 \mathrm{l} \cdot \mathrm{s}^{-1}$ to není málo i s ohledem na to, že velké množství potenciálních metabolizovaných forem pesticidů není zatím měřeno. Nejvyšší odnosy v roce 2016 byly naměřeny právě při spuštění vzorkovací stanice (1. 4. 2016). Při výpočtech látkových odnosů pesticidních látek je tedy nutné zohledňovat i zimní, popř. brzké jarní období.

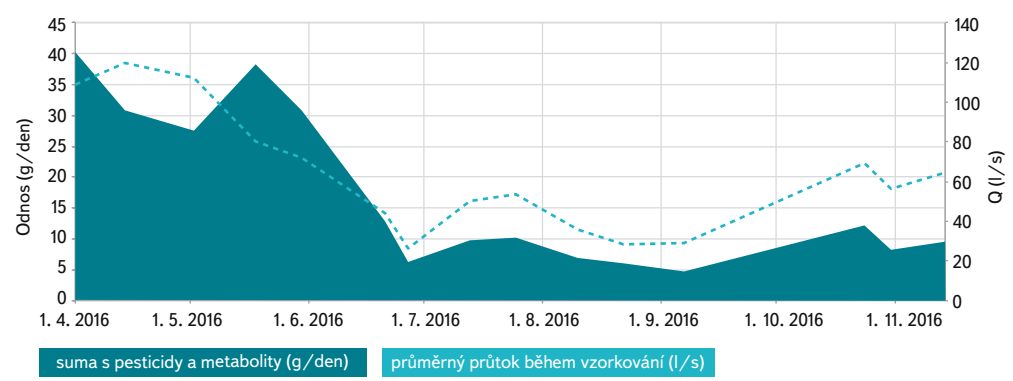

Obr. 11. Látková bilance všech měřených pesticidních látek v Čechtickém potoce na profilu Leský Mlýn v období od 1. 4. do 30. 11. 2016

Fig. 11. Total mass balance of all measured pesticides in the Čechtický brook (1 $1^{\text {st }}$ April-30 ${ }^{\text {th }}$ November 2016)

\section{ZÁVĚR}

Kontinuální vzorkování přináší přesnější výsledky o výskytu a množství pesticidů a jejich metabolitů v průběhu roku. Odnosy těchto látek korelují pozitivně i negativně s průtokem, záleží prìtom na hydrologických podmínkách ve spojení s dobou aplikace látek na zemědělskou půdu [7]. Proto je třeba mít dokonalý přehled o užívání jednotlivých typů látek (ideálně formou spolehlivé elektronické evidence).

Dynamický vývoj v produkci a užívání pesticidů vede k obtižné identifikaci a stanovení nových a zatím neměřených látek [3]. Správci toků musí neustále zavádět nové analyty, dostávají se tak do situace, kdy mají výrazné zpoždění za zemědělskou aplikací.

Koncentrace látek se $v$ povrchové vodě během srážko-odtokových epizod mění v rádu desítek minut, běžný čtyřtýdenní monitoring tak nemůže odhalit dynamiku jejich vyplavování [4]. Velké množství látek, které se na plodiny již dlouhodobě aplikuje, se v našich vodách v různých formách stabilně objevuje. Záleží pouze na tom, jestli jsme schopni tyto látky zachytit a hlavně - situaci řešit [3].

\section{Poděkování}

Tento príspěvek vznikl za podpory projektu TA04021527 Studium príčin a dynamiky zátěže vod drobných vodních toků prípravky na ochranu rostlin, podpořeného agenturou TA ČR. Autoři děkují kolegům z Výzkumného ústavu meliorací a ochrany půdy, v. v. i., za vedení a spolupráci na projektu.

Příspěvek byl publikován ve sborníku Vodní nádrže 2017, ISBN 978-80-905368-5-2.

\section{Literatura}

[1] FIALA, D. Detailní monitoring odnosu fosforu do VD Vranov. Vodní nádrže 2015: 6.-7. řijna 2015, Brno, Česká republika. Brno: Povodí Moravy, s. p., 2015.

\section{[2] Dostupné z: http://hydro.chmi.cz/pasporty/}

[3] KNAUER, K. Pesticides in surface waters: a comparison with regulatory acceptable concentrations (RACS) determined in the authorization process and consideration for regulation. Environ Sci Eur, 2016, vol. 28 , No. 13, p. 1-7.

[4] KODEŠ, V. a GRABIC, R. Screening emergentních polutantů v povrchových vodách pomocí pasivních vzorkovačù. Vodní nádrže 2015: 6.-7. řínna 2015, Brno, Česká republika. Brno: Povodí Moravy, s. p., 2015.

[5] KOSOUR, D. Kontinuální monitoring na LG Ptáčov. Za čistou řeku Jihlavu: 3. 12. 2015, Jihlava, 2015.

[6] LIŠKA, M. a kol. Problematika výskytu pesticidních látek $v$ povrchových vodách $\vee$ povodí vybraných vodárenských zdrojü. Vodní hospodárství, 2015, 1, s. 14-19.

[7] TANG, X., et al. A review of rapid transport of pesticides from sloping farmland to surface waters: Processes and mitigation strategies. Journal of Environmental Sciences, 2012, vol. 24, No. 3, p. 351-361.

[8] Údaje z terénního průzkumu VÚMOP, v. v. i., v rámci řešení projektu TA ČR (č. projektu: TA04021527).

[9] ZAJíČEK, A. a kol. Vyplavování pesticidních látek zemědělskou drenáží. Rostlinolékař, 2017, č. 4, s. 24-28. 


\section{Autoři}

Mgr. Jakub Dobiáš ${ }^{1}$

凶jakub.dobias@pvl.cz

Mgr. Milan Koželuh ${ }^{1}$

凶milan.kozeluh@pvl.cz

Ing. Petr Fučík, Ph.D. ${ }^{2}$

凶ucik.petr@vumop.cz

Mgr. Antonín Zajíček, Ph.D. ${ }^{2}$

凶zajicek.antonin@vumop.cz

RNDr. Marek Liška, Ph.D. ${ }^{1}$

凶marek.liska@pvl.cz

1Povodí Vltavy, s. p.

²Výzkumný ústav meliorací a ochrany půdy, v. v. i.

Príspěvek prošel lektorským řizením.
DYNAMICS OF PESTICIDES LEACHING IN THE ČECHTICKÝ BROOK CATCHMENT AREA

DOBIAS, J.'; KOZELUH, M.'; ZAJICEK, A. ${ }^{2}$; FUCIK, P.'; LISKA, M. ${ }^{2}$

'Povodí Vltavy, state enterprise

${ }^{2}$ Research Institute for Soil and Water Conservation, p. r. i.

Keywords: pesticides - automatic sampling - hydrological event substance balance - Švihov Water Reservoir

The use of automatic samplers for detailed monitoring of substance concentrations and balance is nowadays an important part of special monitoring of surface waters. The average results of routine monitoring (consisting of point samples) are often underestimated over the real situation. The catchment area of Čechtický brook drains one of the most agriculturally managed areas in the entire Švihov Water Reservoir catchment (used as an important source of drinking water). On the Čechtický brook, we run an automatic sampling station since 2012 and in last two years, we obtained some interesting results of pesticides and metabolites concentration from continuous sampling and also from hydrological events (during which the flow increases).

Pesticides concentrations were significantly higher in 2016, than the previous year. Continuous mesurement shows increases in concentrations of maternal pesticides in the spring and their metabolites during the summer. The total balance of all measured pesticides from April to November 2016 was 3,88 kg $\left(Q_{\text {aver }}=63,5 \mathrm{l} / \mathrm{s}\right)$. In the long run, the trends in the pesticides usage are well visible on the example of terbuthylazine (maize growing). Unlike the past, more metabolites are found in the samples. Usage was probably replaced by other active substances. In an effort to detect these new substances, we get into a situation comparable to doping in sport, we have to track new trends, despite we won't be ahead.

We got the most interesting results during the hydrological events, where the concentrations of pesticides increases (or decreases) faster. The dynamics of nutrients and special organic pollution during events is really important. Without that, we can only estimate the real concentrations. 